\title{
TANGGUNG JAWAB BADAN ARBITRASE SYARIAH NASIONAL (BASYARNAS) DALAM PENYELESAIAN SENGKETA PERBANKAN SYARIAH
}

\author{
Muthia Sakti, Yuliana Yuli W \\ Fakultas Hukum UPN "Veteran" Jakarta \\ Jl. R.S. Fatmawati Pondok Labu Jakarta Selatan \\ Email: mutia.sakti@gmail.comi
}

\begin{abstract}
Abstrak
Badan Arbitrasi Syariah Nasional dibentuk oleh Majelis Ulama Indonesia. Alasan pembentukan Badan Arbitrasi Syariah Nasional dengan gagasan Ekonomi Syariah yang ditandai dengan perkembangan perbankan syariah, dengan contoh lahirnya bank syariah yang tentunya mempunyai sengketa yang harus diselesaikan dengan syariah, untuk itu kebutuhan untuk mengikut sertakan pihak-pihak lain untuk mediasi dalam menyelesaikan sengketa syariah. Penelitian ini akan membahas tentang tanggung jawab Badan Arbitrasi Syariah Nasional (BASYARNAS) dalam menyelesaikan sengketa mengenai kewenangan dari bank syariah dan pengadilan agama terhadap pelaksanaan dan pembatalan putusan arbitrase syariah di Indonesia.
\end{abstract}

Kata kunci : Tanggung Jawab, BASYARNAS, Perbankan Syariah

\begin{abstract}
National Sharia Arbitration Board established by the Majelis Ulama Indonesia. The reason the founding of the National Sharia Arbitration Board with their idea of Islamic Economics is characterized by the development of Islamic banking, such as the birth of the Islamic Bank, which certainly has a dispute must be resolved sharia and sharia, so the need to involve other parties to mediate in resolving the dispute sharia. In this thesis will be discussed on the responsibility of the National Sharia Arbitration Board (BASYARNAS) in resolving disputes regarding the authority of Islamic Banking and Religious Court against the execution and cancellation of the decision of the Arbitration Sharia in Indonesia.
\end{abstract}

\section{Keywords : Responsibility, National Sharia Arbitration Board, Sharia Banking}

\section{A. PENDAHULUAN}

1. Latar Belakang

Era globalisasi mempengaruhi semua bidang dalam kehidupan, di satu sisi memang menimbulkan dampak positif, namun di sisi lain juga dapat menimbulkan dampak negatif, seperti misalnya perbedaan paham, perselisihan pendapat ataupun terjadinya sengketa antara pihak yang satu dengan yang lainnya yang telah terikat dalam kesepakatan.

Penyelesaian sengketa di luar pengadilan memiliki kelebihan, yaitu tidak terbuka untuk umum, biaya yang lebih murah, bersifat win-win solution dan fleksibel dibandingkan dengan lembaga peradilan. Arbitrase merupakan salah satu upaya penyelesaian sengketa perdata di luar pengadilan. Pembicaraan mengenai arbitrase memang tidak dapat dilepaskan dengan berbagai peraturan perundang-undangan yang ada. Undang-Undang Nomor 48 Tahun 2009 Tentang Kekuasaan Kehakiman, 
menegaskan bahwa penyelenggaraan kekuasaan kehakiman diserahkan kepada badan peradilan.

Dengan berpedoman pada undang-undang tersebut, keberadaan arbitrase dalam Undang-Undang Nomor 48 Tahun 2009 Tentang Kekuasaan Kehakiman terdapat di dalam penjelasan Pasal 58, 59 Ayat (1), (2), (3), Pasal 60 Ayat (1), (2), (3) dan Pasal 61 yang menyebutkan bahwa "Ketentuan mengenai arbitrase dan penyelesaian sengketa di luar pengadilan sebagaimana dimaksud dalam Pasal 58, Pasal 59, dan Pasal 60 diatur dalam undang-undang"1. Arbitrase Indonesia diatur dalam Undang-Undang Nomor 30 Tahun 1999 Tentang Arbitrase dan Alternatif Penyelesaian Sengketa dan dalam Pasal 1 Angka 1 Undang-Undang Nomor 30 Tahun 1999 memberikan definisi mengenai arbitrase, yaitu "Cara penyelesaian suatu sengketa perdata di luar pengadilan umum yang didasarkan pada perjanjian arbitrase yang dibuat secara tertulis oleh para pihak yang bersangkutan". 2

Munculnya Bank Syariah di Indonesia merupakan fenomena yang menarik dan juga merupakan titik kulminasi dalam upaya panjang beberapa kalangan secara individual atau institusional telah terlibat dalam proses yang berkenaan dengan transformasi sosial masyarakat mereka. Berdasarkan data Bank Syariah Indonesia, pertumbuhan Bank Konvensional jauh ketinggalan oleh Bank Syariah dimana Bank Syariah mengalami pertumbuhan sekitar $40 \%$ per tahun dalam sepuluh tahun terakhir sementara Bank Konvensional hanya $20 \%$. Dari data yang dikeluarkan oleh Bank Indonesia, total asset Bank Syariah mencapai Rp. 125,5 triliun, mengalami peningkatan sebesar Rp. 97,5 triliun dari tahun 2010 dan mencapai pasar sekitar $4 \%$ dari total kue industri Perbankan Nasional. Pertumbuhan Bank Syariah tahun 2012 adalah yang tertinggi sejak tahun 2005. ${ }^{3}$ Akan tetapi, dalam perjalanan kehadiran Bank Syariah di Indonesia, tentu saja belum secepat Bank Konvensional yang sudah ada sejak lama. Proses pertumbuhan dan perkembangan serta pengelolaan Bank Syariah ini masih menghadapi sejumlah masalah.

Berkaitan dengan hal tersebut, permasalahan yang pernah terjadi yaitu sengketa antara Bank Syariah Mandiri dengan PT. Atriumasta Sakti yang diselesaikan melalui Badan Arbitrase Syariah Nasional dengan Putusan Nomor 16/Tahun 2008/BASYARNAS/Ka.Jak, akan tetapi masih mengalami kendala pada saat eksekusi putusan. Hal tersebut dikarenakan pihak yang dikalahkan yaitu Bank Syariah Mandiri merasa bahwa putusan yang dijatuhkan oleh BASYARNAS diambil dari hasil tipu muslihat yang dilakukan oleh PT. Atriumasta Sakti dalam pemeriksaan sengketa. Sehingga Bank Syariah Mandiri kemudian mengajukan permohonan pembatalan putusan Arbitrase Syariah ke Pengadilan Agama Jakarta Pusat sesuai dengan Putusan Nomor 792/Pdt.G/2009/PA.JP, namun dengan adanya putusan tersebut, kemudian PT. Atriumasta Sakti dan Majelis Arbiter Basyarnas mengajukan banding ke Mahkamah Agung. Dimana putusan banding yang diputus oleh Mahkamah Agung kemudian membatalkan putusan Pengadilan Agama dengan pertimbangan bahwa Pengadilan Agama telah melampaui kewenangannya dalam memeriksa dan memutus perkara. Sehingga dengan adanya putusan banding oleh Mahkamah Agung tersebut, PT. Bank

\footnotetext{
${ }^{1}$ Republik Indonesia, Undang-Undang Nomor 48 Tahun 2009 tentang Kekuasaaan Kehakiman, Pasal 58, 59 Ayat 1, 2, 3, Pasal 60 Ayat 1, 2, 3 dan Pasal 61

2 I Made Widnyana, Alternatif Penyelesaian Sengketa dan Arbitrase, Jakarta: PT. Fikahati Aneska,2014, hlm. 10

3 Safri Haliding,"Perbankan Syariah",http//www.dakwatuna.com//2012/07/09/215 35/potensipenyelewengan-di-bank-syariah, di akses tanggal 29 Maret 2016
} 
Syariah Mandiri mengajukan Peninjauan Kembali atas perkara tersebut namun Majelis Mahkamah Agung menolak permohonan Peninjauan Kembali dari PT. Bank Syariah Mandiri.

Pada dasarnya fungsi kedua lembaga Arbitrase yaitu BANI dan BASYARNAS adalah sama-sama berfungsi untuk menegakkan keadilan dengan cara menyelesaikan setiap sengketa yang terjadi antara individu yang satu dengan individu yang lainnya secara adil dan cepat serta memberikan suatu pendapat yang mengikat mengenai suatu persoalan berkenaan dengan perjanjian tersebut. Hanya saja BASYARNAS berfokus untuk menyelesaikan sengketa-sengketa muamalah atau keperdataan dikalangan umat Islam. $^{4}$

\section{Rumusan Masalah}

Berdasarkan latar belakang yang penulis telah kemukakan di atas, maka beberapa pokok permasalahan yang akan penulis rumuskan adalah sebagai berikut:

a. Bagaimana tanggung jawab BASYARNAS dalam penyelesaian Sengketa Perbankan Syariah?

b. Bagaimana kewenangan Pengadilan Agama terhadap eksekusi dan pembatalan putusan Arbitrase Syariah di Indonesia?

\section{Tujuan Penelitian}

a. Untuk mengetahui mengenai tanggung jawab BASYARNAS dalam penyelesaian Sengketa Perbankan Syariah.

b. Untuk mengetahui kewenangan Pengadilan Agama terhadap eksekusi dan pembatalan putusan Arbitrase Syariah di Indonesia.

\section{Metode Penelitian}

Dalam penelitian ini digunakan sarana penelitian ilmiah yang berdasarkan pada metode penelitian. Penulis menggunakan metode penelitian yang berjenis yuridis normatif, pendekatan berdasarkan peraturan-peraturan perundang-undangan yang berlaku, yang kemudian ditelaah lebih lanjut sesuai dengan perumusan masalah, sehingga uraian tersebut dapat ditarik suatu kesimpulan yang bersifat logis. Adapun pendekatan yang digunakan dalam penelitian ini adalah pendekatan perundangundangan atau normatif approach._Penelitian ini bersifat deskriptif analitis dengan menggambarkan peraturan perundang-undangan yang berlaku dan dikaitkan dengan teori -teori hukum dalam pelaksanaannya yang berkaitan dengan permasalahan yang akan diteliti. Dari keseluruhan data yang terkumpul, akan diseleksi atas dasar reabilitas (kejujuran) maupun validitas (keabsahan).

\section{B. PEMBAHASAN}

1. Tanggung Jawab BASYARNAS dalam Penyelesaian Sengketa Perbankan Syariah

Menurut Kamus Besar Bahasa Indonesia (KBBI), tanggung jawab dapat diartikan sebagai kewajiban menanggung segala sesuatunya bila terjadi apa-apa boleh dituntut, dipersalahkan, dan diperkarakan. Dalam kamus hukum, tanggung jawab adalah suatu keharusan bagi seseorang untuk melaksanakan apa yang telah diwajibkan kepadanya. Menurut hukum, tanggung jawab adalah suatu akibat atas konsekuensi kebebasan

\footnotetext{
${ }^{4}$ Rahmat Rosyadi dan Ngantino, Arbitrase Dalam Perspektif dan Hukum Positif, Bandung : PT. Citra Aditya Bakti, 2002, hlm. 49-71
} 
seseorang tentang perbuatannya yang berkaitan dengan etika atau moral dalam melakukan suatu perbuatan. Selanjutnya menurut Titik Triwulan pertanggungjawaban harus mempunyai dasar, yaitu hal yang menyebabkan timbulnya hak hukum bagi seorang untuk menuntut orang lain sekaligus berupa hal yang melahirkan kewajiban hukum orang lain untuk memberi pertanggungjawabannya. ${ }^{5}$

Menurut hukum perdata, dasar pertanggungjawaban dibagi menjadi 2 (dua) macam, yaitu kesalahan dan risiko. Dengan demikian dikenal dengan pertanggungjawaban atas dasar kesalahan (liability without based on fault) dan pertanggungjawaban tanpa kesalahan yang dikenal dengan tanggung jawab risiko (liability without fault) atau tanggung jawab mutlak (strick liability). ${ }^{6}$

Dalam kosa kata Inggris terdapat 2 (dua) istilah, yakni conflict dan Dispute yang kedua-duanya mengandung pengertian tentang adanya perbedaan kepentingan di antara kedua pihak atau lebih, tetapi keduanya dapat dibedakan kosa kata conflict sudah diserap ke dalam bahasa Indonesia menjadi "konflik", sedangkan kosa kata Dispute dapat diterjemahkan menjadi kosa kata "sengketa".

Sebuah konflik berubah atau berkembang menjadi sebuah sengketa bilamana pihak yang merasa dirugikan telah menyatakan rasa tidak puas atau keprihatinannya, baik secara langsung kepada pihak yang dianggap sebagai penyebab kerugian atau kepada orang lain. ${ }^{7}$ Ini berarti sengketa merupakan kelanjutan dari konflik. Sebuah konflik akan berubah menjadi sengketa bila tidak dapat terselesaikan. Konflik akan diartikan pertentangan diantara para pihak untuk menyelesaikan masalah yang kalau tidak terselesaikan dengan baik dapat mengganggu hubungan diantara mereka.

Sektor perbankan dengan posisi strategis sebagai lembaga intermediasi dan penunjang sistem perbankan merupakan faktor yang sangat menentukan dalam pembangunan nasional. Bank sebagai lembaga perantara dana (financial intermediary) memiliki tugas pokok menghimpun dana masyarakat dalam bentuk simpanan dan menyalurkannya kembali dalam bentuk kredit. Bank mempunyai peranan strategis dalam pembangunan nasional yang memerlukan kepercayaan dari masyarakat sehingga melaksanakan tugas pokoknya dengan baik.

Keberadaan Bank Syariah hanya menjadi salah satu bagian dari program perkembangan Bank Konvensional, karena pengembangan Perbankan Syariah sendiri pada awalnya ditujukan dalam rangka pemenuhan pelayanan bagi segmen masyarakat yang belum memperoleh pelayanan jasa perbankan karena sistem Perbankan Konvensional dipandang tidak sesuai dengan prinsip Syariah yang diyakini. Pengembangan Perbankan Syariah juga dimaksudkan sebagai perbankan alternatif yang memiliki karakteristik dan keunggulan tertentu. Unsur moralitas menjadi faktor penting dalam seluruh kegiatan usahanya. Kontrak pembiayaan yang lebih menekankan sistem bagi hasil mendorong terciptanya pola hubungan kemitraan (Mutual investor relationship), memperhatikan prinsip kehati-hatian dan berupaya memperkecil resiko kegagalan usaha.

Selain penyempurnaan terhadap sisi kelembagaan, perlu juga memperhatikan sisi hukum sebagai landasan penyelenggaraannya hal ini untuk mengantisipasi

\footnotetext{
${ }^{5}$ Titik Triwulan dan Shinta Febrian, Perlindungan Hukum bagi Pasien, Jakarta: Prestasi Pustaka , 2010, hlm. 48

${ }^{6}$ Ibid., hlm. 49

7 Siti Megadianty Adam dan Takdir Rahmadi, "Sengketa dan Penyelesaiannya: Buletin Musyawarah", Indonesia Center for Environmental Law, Nomor 1 Tahun I Jakarta, 1997, hlm.1
} 
munculnya berbagai macam permasalahan dalam operasionalnya. Penyelesaian sengketa Ekonomi Syariah sebagai sengketa perdata, dalam hal ini termasuk sengketa Perbankan Syariah, dapat diselesaikan melalui cara musyawarah. Namun apabila cara musyawarah tidak berhasil, maka penyelesaian dapat dilakukan melalui 2 (dua) cara, yakni penyelesaian secara litigasi di Pengadilan Agama dan non litigasi (diluar pengadilan). Pilihan penyelesaian sengketa secara non litigasi dapat dibagi 2 (dua), yaitu Arbitrase dan Alternatif Penyelesaian Sengketa.

Ketentuan mengenai arbitrase di Indonesia diatur dalam Undang-Undang Nomor 30 Tahun 1999 tentang Arbitrase dan Alternatif Penyelesaian Sengketa. Di dalam Pasal 1 angka 8 Undang-Undang Nomor 30 Tahun 1999 tentang Arbitrase dan Alternatif Penyelesaian Sengketa, disebutkan bahwa Lembaga Arbitrase adalah badan yang dipilih oleh para pihak yang bersengketa untuk memberikan putusan mengenai sengketa tersentu; lembaga tersebut juga dapat mmeberikan pendapat yang mengikat mengenai suatu hubungan hukum tertentu dalam hal belum timbul sengketa. Kewenangan arbitrase menyelesaikan perbankan Syariah dapat didasarkan atas kesepakatan ketika membuat perjanjian (pactum de compromittendo) atau dibuat ketika terjadi sengketa (akta kompromi). Pilihan ini disebabkan banyaknya kelebihan arbitrase dibandingkan dengan proses melalui jalur litigasi.

Sesuai dengan Visi dan Misi berdirinya BASYARNAS, sebagai Arbitrase Islam yang tentunya berlandaskan Islam dan nilai-nilai Agama dalam menyelesaikan sengketa Perbankan Syariah maupun sengketa lainnya yang juga berlandaskan Islam, maka penerapan BASYARNAS dalam menyelesaikan perbankan Syariah yang sering terjadi hingga saat ini harus tetap mengutamakan prinsip kedamaian dan mencerminkan rasa keadilan bagi para pihak yang bersengketa. Dalam hal ini, proses beracara di BASYARNAS berjalan maksimal 6 (enam) bulan dan harus diselesaikan secara tuntas dengan cara Arbiter/Hakam memberikan keputusan yang bersifat final dan binding/ mengikat dan tidak dapat diganggu gugat. Sehingga keputusan Arbiter/Hakam tersebut memiliki kekuatan hukum tetap.

Seorang Arbiter/Hakam harus mampu membuat suasana proses arbitrase bersih, jelas dan bebas dari argumentasi forensik. Ia harus mampu menilai buku-bukti yang diajukan, berhubungan dengan sengketa yang akan diselesaikan. Seorang Arbiter juga harus memperhatikan fakta-fakta yang muncul yang berkaitan dengan permasalahan sengketa dan putusannya harus berdasarkan sesuatu yang bersifat praktis atau tidak memihak, wajar dan adil. Selain itu, ia juga harus memiliki pengetahuan dasar tentang prosedur arbitrase, hukum, tata cara pembuktian, faham akan hukum kontrak, hukum hak milik dan sudah tentu terutama hukum-hukum arbitrase itu sendiri. Para pihak yang bersengketa berhak melakukan penilaian yang dipermasalahkan sejak awal pada saat dengar pendapat dan berhak menilai para arbitrer apakah ia telah bertindak di dalam wewenang yang telah disepakati menurut hukum. Oleh karena itu, BASYARNAS memiliki tanggung jawab terhadap semua penyelesaian sengketa Perbankan Syariah maupun sengketa Syariah lainnya terutama bagi seorang Arbiter/Hakam. Terhitung dari mulai berdirinya hingga sampai saat ini ada 20 (dua puluh) sengketa perbankan Syariah yang masuk dan dituntaskan oleh BASYARNAS.

Kewenangan Badan Arbitrase Syariah Nasional (BASYARNAS) diatur dalam Pasal 1 Peraturan Prosedur Badan Arbitrase Syariah Nasional (BASYARNAS), yakni:

a. Menyelesaikan secara adil dan cepat sengketa muamalah (perdata) yang timbul dalam perdagangan, keuangan, industri, jasa dan lain-lain yang menurut hukum dan peraturan perundang-undangan dikuasai sepenuhnya 
oleh pihak yang bersengketa, dan para pihak sepakat secara tertulis untuk menyerahkan penyelesaiannya kepada Badan Arbitrase Syariah Nasional (Basyarnas) sesuai dengan prosedur Badan Arbitrase Syariah Nasional (Basyarnas);

b. Memberikan pendapat yang mengikat atas permintaan para pihak tanpa adanya suatu sengketa mengenai persoalan berkenaan dengan suatu perjanjian.

\section{Kewenangan Pengadilan Agama dalam Eksekusi dan Pembatalan Putusan BASYARNAS}

Istilah wewenang atau kewenangan disejajarkan dengan Authority dalam bahasa Inggris dan bevoegdheid dalam bahasa Belanda. Authority dalam Black $S$ Law Dictionary, diartikan sebagai kewenangan atau wewenang adalah kekuasaan hukum, hak untuk memerintah atau bertindak; hak atau kekuasaan pejabat publik untuk mematuhi aturan hukum dalam lingkup melaksanakan kewajiban publik.

Dalam dunia bisnis, sekalipun dibidang kegiatan ekonomi syariah, para pihak ingin cepat menyelesaikan sengketa mereka secara adil, dan bisnis dapat berjalan kembali tanpa adanya kendala apapun. Menurut peraturan hukum Arbitrase Indonesia dan pengalaman arbitrase terlembaga domestik Indonesia, suatu sengketa bisnis sudah dapat mempunyai kekuatan hukum tetap dalam waktu paling lama 1 (satu) tahun, termasuk apabila ada permohonan pembatalan putusan arbitrase. Dibandingkan melalui lembaga peradilan yang memakan waktu paling sedikit 4 (empat) tahun, belum termasuk upaya hukum luar biasa, Peninjauan Kembali. Biasanya suatu pengurusan penyelesaian sengketa yang memakan waktu bertahun-tahun akan menghabiskan waktu dan biaya yang tidak sedikit. Apalagi aparat penyelenggara negara kita belum dapat memberikan suasana kondusif dalam penegakan hukum peradilan di Indonesia.

Badan Arbitrase Syariah Nasional (BASYARNAS) adalah satu-satunya lembaga arbitrase Islam di Indonesia. Secara formal, eksistensi lembaga ini mempunyai dasar hukum yang kuat dalam struktur hukum Indonesia. Undang-Undang di Indonesia memberikan peluang bagi para pihak yang bersengketa ke lembaga independen di luar pengadilan. Hal ini diatur secara tegas dalam Undang-Undang Nomor 30 Tahun 1999 tentang Arbitrase dan Alternatif Penyelesaian Sengketa dan Undang-Undang Nomor 48 Tahun 2009 tentang Kekuasaan Kehakiman. Dimaksud pada Pasal 58 Undang-Undang Kekuasaan Kehakiman menyatakan bahwa upaya penyelesaian sengketa perdata dapat dilakukan diluar pengadilan negara melalui arbitrase atau penyelesaian sengketa alternatif. BASYARNAS merupakan lembaga yang memiliki kewenangan dalam menyelesaikan sengketa perbankan dan keuangan syariah, karena tujuan utama didirikannya lembaga ini adalah untuk menyelesaikan sengketa muamalat di bidang perdagangan, keuangan, perbankan jasa dan sebagainya secara cepat dan adil berdasarkan pada prinsip syariah.

Penyelesaian sengketa melalui BASYARNAS bersifat rahasia (confidential). Sebelum pemeriksaan sengketa dimulai, arbiter harus terlebih dahulu mendamaikan para pihak yang bersengketa. Apabila perdamaian (islah) tersebut tercapai, maka arbiter akan mencatatnya sebagai kesepakatan bersama yang mengikat dan harus di patuhi oleh para pihak yang bersengketa. Namun, apabila perdamaian tidak tercapai, maka pemeriksaan dilanjutkan sesuai dengan peraturan yang berlaku. Sengketa harus selesai dalam waktu 6 (enam) bulan. Pelaksanaan putusan Badan Arbitrase Syariah Nasional (BASYARNAS) sama dengan aturan yang berlaku dalam Badan Arbitrase Nasional 
Indonesia (BANI) yang berkiblat pada Pasal 59-64 Undang-Undang Nomor 30 Tahun 1999 tentang Arbitrase dan Alternatif Penyelesaian Sengketa. Pada dasarnya para pihak harus melaksanakan putusan tersebut dengan sukarela, agar putusan arbitrase dapat dipaksakan pelaksanaannya, maka putusan harus diserahkan dan didaftarkan kepada Kepaniteraan Pengadilan Negeri.

Putusan yang diberikan arbiter bersifat final dan mempunyai kekuatan hukum tetap dan mengikat para pihak yang bersengketa (sesuai dalam Pasal 60 UndangUndang Nomor 30 Tahun 1999 tentang Arbitrase dan Alternatif Penyelesaian Sengketa) sehingga Ketua Pengadilan tidak diperkenankan memeriksa alasan atau pertimbangan dari putusan arbitrase tersebut. ${ }^{8}$ Kewenangan memeriksa yang dimiliki oleh Ketua Pengadilan, terbatas pada pemeriksaan secara formal terhadap putusan arbitrase yang dijatuhkan oleh arbiter atau majelis arbiter. Putusan BASYARNAS, sesuai dengan Pasal 59 ayat (1) Undang-Undang Nomor 30 Tahun 1999, didaftarkan oleh arbiter atau kuasa hukumnya kepada Panitera Pengadilan Negeri. Apabila ada salah satu pihak yang bersegketa enggan melaksanakan putusan arbitrase secara sukarela, maka pihak lainnya bisa mengajukan permohonan eksekusi kepada Ketua Pengadilan Negeri dengan mengajukan permohonan eksekusi kepada Ketua Pengadilan Negeri dengan mendaftarkan permohonan tersebut kepada Panitera Pengadilan Negeri (sesuai dengan Pasal 61 dan 62 Undang-Undang Nomor 30 Tahun 1999 tentang Arbitrase dan Alternatif Penyelesaian Sengketa).

Sejak tahun 2006, dengan diamandemennya Undang-Undang Nomor 7 Tahun 1989 dengan Undang-Undang Nomor 3 Tahun 2006, kewenangan Pengadilan Agama menjadi diperluas. Disamping berwenang memeriksa, memutus, dan menyelesaikan sengketa di tingkat pertama antara orang-orang yang beragama Islam di bidang perkawinan, waris, wasiat, hibah, wakaf, zakat, infaq, dan shadaqah, Pengadilan Agama juga berwenang untuk memeriksa, memutus, dan menyelesaikan sengketa di bidang ekonomi syariah. Selanjutnya, kewenangan Peradilan Agama tersebut diperkuat dengan putusan Mahkamah Konstitusi atas perkara Nomor 93/PUU-X/2012 yang menghapuskan penjelasan Pasal 55 ayat (2) Undang-Undang Nomor 21 Tahun 2008 tentang Perbankan Syariah, sehingga menjadikan Peradilan Agama satu-satunya lembaga Peradilan yang berwenang untuk menyelesaikan sengketa ekonomi syariah.

Dalam penjelasan Pasal 55 ayat (2) Undang-Undang Nomor 21 Tahun 2008 tentang Perbankan Syariah pada huruf (d) menentukan, bahwa yang dimaksud dengan penyelesaian sengketa dilakukan dengan Akad adalah melalui pengadilan dalam lingkungan Peradilan Umum. Namun penjelasan pasal tersebut kemudian oleh Mahkamah Konstitusi dinyatakan bertentangan dengan Undnag-Undang Dasar Negara Republik Indonesia Tahun 1945 dan tidak mempunyai kekuatan hukum tetap. Selain itu, pada Penjelasan Pasal 59 ayat (1) Undang-Undang Nomor 48 Tahun 2009 tentang Kekuasaan Kehakiman, yang menyatakan bahwa yang dimaksud dengan arbitrase dalam ketentuan ini termasuk juga arbitrase Syariah.

Kemudian berdasarkan ketentuan tersebut Mahkamah Agung membatalkan Surat Edaran Mahkamah Agung Nomor 08 Tahun 2008 tentang Eksekusi Putusan Badan Arbitrase Syariah yang menjadi landasan kewenangan bagi Pengadilan Agama untuk memerintahkan pelaksanaan (eksekusi) dan pembatalan putusan Badan Arbitrase Syariah Nasional sebagaimana diuraikan diatas, dengan menerbitkan Surat Edaran Mahkamah Agung Nomor 08 Tahun 2010 tentang Penegasan Tidak Berlakunya Surat

\footnotetext{
${ }^{8}$ Ahmad Mujahidin, Prosedur Penyelesaian Sengketa Ekonomi Syariah di Indonesia, Bogor: Galia Indonesia, 2010, hlm. 150-151
} 
Edaran Mahkamah Agung Nomor 08 Tahun 2008 tentang Eksekusi Putusan Badan Arbitrase Syariah dengan alasan bahwa berdasarkan Pasal 59 ayat (3) Undang-Undang Nomor 48 Tahun 2009 tentang Kekuasaan Kehakiman dan Penjelasannya yang menyatakan bahwa dalam hal para pihak tidak melaksanakan putusan arbitrase (termasuk arbitrase Syariah) secara sukarela, putusan dilaksanakan berdasarkan perintah Ketua Pengadilan Negeri atas permohonan salah satu pihak yang bersengketa, sehingga terhitung sejak berlakunya Undang-Undang Nomor 48 Tahun 2009 tentang Kekuasaan Kehakiman tersebut maka Surat Edaran Mahkamah Agung Nomor 08 Tahun 2008 Tentang Eksekusi Putusan Badan Arbitrase Syariah, dinyatakan tidak berlaku lagi.

Tidak hanya Mahkamah Agung yang kemudian menyatakan tidak berlakunya Surat Edaran Mahkamah Agung Nomor 08 Tahun 2008 tentang Eksekusi Putusan Badan Arbitrase Syariah, Dewan Syariah Nasional (DSN) juga tidak lagi mencantumkan kalimat "dan melalui Pengadilan Agama" pada ketentuan penyelesaian sengketa. Dari uraian tersebut, menunjukkan bahwa terdapat disharmonisasi hukum di bidang kekuasaan kehakiman, khususnya mengenai kewenangan Peradilan Agama dalam memeriksa, memutus dan menyelesaikan sengketa Ekonomi Syariah sehingga timbul tarik ulur penyelesaian hukum ekonomi Syariah.

\section{SIMPULAN DAN SARAN}

1. Simpulan

a. Tanggung Jawab BASYARNAS dalam penyelesaian sengketa Perbankan Syariah yang paling utama adalah berpegang teguh pada Prosedur Beracara di BASYARNAS dan peraturan perundang-undangan serta terhadap sumber hukum yang ada. Dalam hal ini, Arbiter/Hakam bertanggung jawab tidak hanya kepada para pihak, tetapi kepada Allah SWT, dengan melihat bukti-bukti yang kuat atau otentik dari para pihak yang bersengketa, Arbiter/Hakam dengan mencerminkan rasa keadilan harus memberikan keputusan sesuai dengan ajaran Agama Islam. Tanggung jawab BASYARNAS dalam menyelesaikan sengketa Perbankan Syariah dinilai masih kurang efektif, hal tersebut dikarenakan tanggung jawab BASYARNAS terhadap sengketa yang diselesaikan hanya sampai pada tahap putusan oleh Majelis Arbiter, bukan sampai tahap eksekusi putusan dimana para pihak yang bersengketa dapat dengan sukarela melaksanakan putusan BASYARNAS tersebut.

b Kewenangan Pengadilan dalam hal eksekusi dan pembatalan putusan BASYARNAS yang berwenang secara absolut adalah Pengadilan Negeri. Alasannya dengan mengingat pasca Undang-Undang Nomor 3 Tahun 2006 tentang Perubahan Undang-Undang Nomor 7 Tahun 1989 tentang Peradilan Agama diundangkan, dan dikaitkan dengan Undang-Undang Nomor 21 Tahun 2008 tentang Perbankan Syariah jo. Undang-Undang Nomor 48 Tahun 2009 tentang Kekuasaan Kehakiman, menjelaskan bahwa sengketa Ekonomi Syariah merupakan kewenangan Pengadilan Agama sebagai penyelesaian sengketa melalui jalur litigasi, namun para pihak yang melakukan perjanjian akad dalam klausul perjanjian dapat menyelesaikan sengketa yang timbul melalui Badan Arbitrase Syariah Nasional dan kedudukan Arbitrase ini merupakan penyelesaian sengketa Ekonomi Syariah melalui jalur non litigasi, sementara eksistensinya telah diakui secara yuridis dalam konstitusi. Selanjutnya mengenai eksekusi dan pembatalan putusan Badan Arbitrase Syariah Nasional, dengan tidak berlakunya lagi Surat Edaran Mahkamah Agung yang semula 
menyatakan bahwa eksekusi dan pembatalan putusan Badan Arbitrase Syariah Nasional (BASYARNAS) merupakan kewenangan Pengadilan Agama, maka saat ini kewenangan untuk eksekusi dan pembatalan putusan Badan Arbitrase Syariah Nasional (BASYARNAS) menjadi kewenangan Pengadilan Negeri sesuai dengan ketentuan Undang-Undang Nomor 30 Tahun 1999 tentang Arbitrase dan Alternatif Penyelesaian Sengketa.

\section{Saran}

a. Seiring perkembangan Ekonomi Syariah yang tidak lepas dari segala kemungkinan terjadinya sengketa dalam setiap kegiatan usahanya, maka peranan BASYARNAS sebagai lembaga penyelesaian sengketa ekonomi Syariah di luar pengadilan akan semakin meningkat. Terkait hal itu BASYARNAS harus melakukan terobosan dan upaya-upaya perbaikan sistem lainnya. Antara lain, sebaiknya BASYARNAS memiliki Term Of Reference (TOR) yang tegas mengatur mengenai eksekusi putusan BASYARNAS dan mengacu pada ICC Arbitration Rules. Sehingga putusan BASYARNAS memiliki kekuatan hukum bagi para pihak yang menyelesaikan sengketa melalui Arbitrase. Dengan adanya Term Of Reference (TOR) yang mengatur mengenai eksekusi putusan BASYARNAS, maka akan meminimalisir terjadinya pembatalan putusan dan perbuatan ingkar salah satu pihak terhadap putusan BASYARNAS serta lebih membuktikan bahwa BASYARNAS memiliki peran dan tanggung jawab yang mutlak terhadap sengketa yang diselesaikan hingga putusan BASYARNAS tersebut dilaksanakan oleh para pihak.

b. Untuk menjamin kepastian hukum, perlu adanya harmonisasi ketentuan perundang-undangan secara vertikal, sebagai landasan bagi eksekusi putusan BASYARNAS. Sehingga akan tercipta ketentuan peraturan perundangundangan yang selaras dan saling berkesinambungan terkait permohonan eksekusi putusan BASYARNAS. Untuk itu, menurut penulis ada baiknya Pemerintah merevisi Undang-Undang Nomor 30 Tahun 1999 tentang Arbitrase dan Alternatif Penyelesaian Sengketa dengan menambahkan ketentuan mengenai Arbitrase Syariah secara khusus. Demikian pula Undang-Undang lain yang erat kaitannya dengan arbitrase Syariah, agar terwujudnya harmonisasi hukum dalam penyelesaian sengketa ekonomi Syariah.

\section{DAFTAR PUSTAKA}

\section{Buku:}

Adam, Siti Megadianty dan Takdir Rahmadi, 1997. Sengketa dan Penyelesaiannya: Buletin Musyawarah, Nomor 1 Tahun I, Indonesia Center for Environmental Law, Jakarta

Mujahidin, Ahmad, 2010. Prosedur Penyelesaian Sengketa Ekonomi Syariah di Indonesia, Bogor: Ghalia Indonesia

Rosyandi, Rahmad, dan Ngatino, 2002, Arbitrase dalam Perspektif dan Hukum Positif, Bandung: PT. Citra Aditya Bakti.

Triwulan, Titik dan Sinta Febrian. 2010. Perlindungan Hukum Bagi Pasien. Widnyana, I Made. 2014. Alternatif Penyelesaian Sengketa dan Arbitrase. Jakarta: PT. Fikahati Aneska 


\section{Peraturan Perundangan-Undangan:}

Republik Indonesia, Undang-Undang Nomor 7 Tahun 1989 Tentang Peradilan Agama, LN RI Nomor 49 Tahun 1989, TLN RI Nomor 3400.

, Undang-Undang Nomor 3 Tahun 2006 Tentang Perubahan Atas UndangUndang omor 7 Tahun 1989 Tentang Peradilan Agama, LN RI Nomor 22 Tahun 2006, TLN RI Nomor 4611.

Undang-Undang Nomor 50 Tahun 2009 Tentang Perubahan Kedua Atas Undang-Undang Nomor7 Tahun 1989 Tentang Peradilan Agama, LN RI Nomor 159 Tahun 2009, TLN RI Nomor 5078.

, Undang-Undang Nomor 48 Tahun 2009 Tentang Kekuasaan Kehakiman, LN RI Nomor 157 Tahun 2009, TLN RI Nomor 5076.

Undang-Undang Nomor 30 Tahun 1999 Tentang Arbitrase dan Alternatif Penyelesaian Sengketa, LN RI Nomor 74 Tahun 1970, TLN RI Nomor 2951.

Undang-Undang Nomor 10 Tahun 1998 Tentang Perubahan Atas UndangUndang Nomor 7 Tahun 1992 Tentang Perbankan, LN RI Nomor 63 Tahun 1963, TLN RI Nomor 2865.

, Undang-Undang Nomor 3 Tahun 2004 Tentang Perubahan Atas UndangUndang Nomor 23 Tahun 1999 Tentang Bank Indonesia, LN RI Nomor 66 Tahun 1999, TLN RI Nomor 3843.

Undang-Undang Nomor 21 Tahun 2008 Tentang Perbankan Syariah, LN RI Nomor 31 Tahun 1992, TLN RI Nomor 4357.

\section{Internet}

Safri Haliding, "Perbankan Syariah", http//www.dakwatuna.com//2012/ $\underline{07 / 09 / 21535 / \text { potensi-penyelesaian-di-bank-syariah }}$ 